Економічні науки: збірник наукових прачь Луиького національного технічного університету. Серія "Регіональна економіка". Випуск 17 (67). Редкол.: відп. ред. к.е.н., професор І.В. Кривов’язюк. Луцьк: ІВВ Луцького НТУ, 2020. 348 с.

УДК 352.07:658.8

Кривов'язюк І.В., к.е.н., професор

Волинчук Ю.В., к.е.н., доцент

Луцький національний технічний університет

\title{
СОЦІАЛЬНА ЛОГІСТИКА І РОЗВИТОК ОБ'ЄДНАНИХ ТЕРИТОРІАЛЬНИХ ГРОМАД: ТОЧКИ ДОТИКУ ТА ОСОБЛИВОСТІ УПРАВЛІННЯ
}

В даній статті вирішено складне наукове завдання - поглиблення існуючих теоретико-методичних положень і надання практичних рекомендацій, спрямованих на оптимізацію протікання внутрішньо-суспільних процесів під час управління об'єднаними територіальними громадами. Шляхом критичного аналізу наукових публікацій учених сучасності розкрито підходи щодо тлумачення та уточнено сутність поняття “соціальна логістика" в контексті вирішення соціально-територіальних проблем регіонів. Проаналізовано показники розвитку провідних об'єднаних територіальних громад регіонів України. 
Економічні науки: збірник наукових прачь Луиького національного технічного університету. Серія "Регіональна економіка". Випуск 17 (67). Редкол.: відп. ред. к.е.н., професор І.В. Кривов’язюк. Луцьк: ІВВ Луцького НТУ, 2020. 348 с.

Встановлено, що високорозвинені громади переважно тяжіють до середніх i великих міст, або ж мають прикордонне місце розташування. SWOT-аналіз розвитку об'єднаних територіальних громад регіону виявив, що використання їх можливостей поряд 3 використанням методів децентралізованого управління здатне підсилювати сильні сторони та вирішувати наявні їх соціальноекономічні проблеми. Застосування проблемно-цільового підходу в управлінні об'єднаними територіальними громадами забезпечує цільове спрямування соціальної логістики та оптимізацію протікання внутрішньо суспільних потоків.

Ключові слова: соціальна логістика, об'єднані територіальні громади, децентралізація, сталий розвиток, дерево проблем, оптимізація ресурсів.

\section{Kryvovyazyuk I.V., Volynchuk Yu.V. \\ SOCIAL LOGISTICS AND DEVELOPMENT OF UNITED TERRITORIAL COMMUNITIES: POINTS OF CONTACT AND MANAGEMENT FEATURES}

This article solves a complex scientific task - improving existing theoretical and methodological provisions and providing practical recommendations aimed at optimizing the flow of internal social processes in the management of united territorial communities. Based on a critical analysis of the articles of scientists revealed the need to use social logistics to improve the management of social systems, improve their functioning and the course of internal social processes. The analysis of approaches to defining the essence of the concept of "social logistics" became the basis for clarifying its essential content as a universal tool for optimizing the flow of internal-social processes aimed at improving the management of social systems.

The research of the development of united territorial communities was conducted based on monitoring the process of decentralization of govermance and reform of local self-government, as well as annual indicators of budget execution in the regions of Ukraine. The analysis of the functioning of the united territorial communities of Ukraine showed that their development is uneven: the regions with the highest rating of indicators include Zhytomyr, Dnipropetrovsk, Khmelnytskyi, Chernihiv and Zaporizhia regions; Kirovohrad, Zakarpattia, Vinnytsia, Kyiv and Lviv regions are among the regions with the lowest rating indicators; all other regions are among those with an average rating.

Analysing the logistical aspect, it was determined that one of the factors in the development of united territorial communities is their territorial location. It has been established that highly developed communities tend to be near medium and large cities, or have a border location. This accordingly affects the indicators of their socioeconomic development. The closer the centre of gravity is, the better the relevant socio-economic indicators are. A SWOT analysis of the development of the united territorial communities of the region revealed that the use of their opportunities, along with the use of decentralized management methods, can strengthen the strengths and solve their existing socio-economic problems. This analysis showed that high human 
Економічні науки: збірник наукових прачь Луиького національного технічного університету. Серія "Регіональна економіка". Випуск 17 (67). Редкол.: відп. ред. к.е.н., професор І.В. Кривов’язюк. Луцьк: ІВВ Луцького НТУ, 2020. 348 с.

resources potential is a resource for participation in international projects, the development of agribusiness can increase the level of entrepreneurial activity of united territorial communities, and the outflow of active and qualified personnel abroad will limit the development of existing enterprises and attracting foreign investors.

The application of a problem-target approach in the management of united territorial communities provides a targeted direction of social logistics and optimization of internal social flows. Based on the "problem tree" method, the reasons for the lack of unification of territorial communities were identified: bureaucratization of the process, low level of information on the need for unification, lack of local leadership and corruption component. In the context of decentralization reform, it is recommended to use international donation, as well as programs and projects that promote the development of united territorial communities; special attention should be paid to community cooperation and improvement of communication processes with society and investors, development of social interaction through the media and the Internet.

Key words: social logistics, united territorial communities, decentralization, sustainable development, problem tree, resource optimization.

\section{Кривовязюк И.В., Волынчук Ю.В. СОЦИАЛЬНАЯ ЛОГИСТИКА И РАЗВИТИЕ ОБЪЕДИНЕННЫХ ТЕРРИТОРИАЛЬНЫХ ОБЩИН: ТОЧКИ СОПРИКОСНОВЕНИЯ И ОСОБЕННОСТИ УПРАВЛЕНИЯ}

В данной статье решена сложная научная задача - углубление существующих теоретико-методических положений и разработка практических рекомендаций по оптимизации протекания внутри общественных процессов во время управления объединенными территориальными общинами. Путем критического анализа научных публикаций ученых современности раскрыто подходы к толкованию и уточнена сущность понятия “социальная логистика" в контексте решения социально-экономических проблем регионов. Проанализированы показатели развития ведущих объединенных территориальных общин регионов Украины. Установлено, что высокоразвитые общины преимущественно тяготеют к средним и крупным городам, или же имеют пограничное положение. SWOT-анализ развития объединенных территориальных общин региона обнаружил, что использование их возможностей наряду с внедрением методов децентрализованного управления усиливает сильные стороны и решает имеющиеся социально-экономические проблемы. Применение проблемно-целевого подхода в управлении объединенными территориальными общинами обеспечивает целевое направление социальной логистики и оптимизацию протекания внутри общественных потоков. 
Економічні науки: збірник наукових прачь Луиького національного технічного університету. Серія "Регіональна економіка". Випуск 17 (67). Редкол.: відп. ред. к.е.н., професор І.В. Кривов'язюк. Луиьк: ІВВ Луцького НТУ, 2020. 348 с.

Ключевые слова: социальная логистика, объединенные территориальные общины, децентрализация, устойчивое развитие, дерево проблем, оптимизация ресурсов.

Постановка проблеми у загальному вигляді та ії зв'язок 3 важливими науковими й практичними завданнями. Функціонування та розвиток об'єднаних територіальних громад (ОТГ) - одна 3 найактуальніших тем сьогодення. Нині близько $30 \%$ українців проживають в ОТГ, при цьому число їх зростає кожного місяця. Забезпечення ефективної співпраці на внутрішньому та зовнішньому рівні одна із задач соціальної логістики. Оптимізація ресурсів: матеріальних, інформаційних, людських - це те, над чим працює реформа децентралізації. Центральні органи управління делегують прийняття рішень на рівень громад, що повинно покращити життя людей, особливо малонаселених пунктів. Саме тому важливим науковим завданням сьогодення $\epsilon$ оптимізація протікання внутрішньо-суспільних процесів під час управління ОТГ.

Аналіз останніх досліджень і публікацій. Попередньо нами було проведено поглиблене дослідження логістики на мікроекономічному рівні [1-3], що виявило ряд зовнішніх факторів впливу та соціально значимих їх параметрів, які вказують на доцільність зосередження уваги на сучасному етапі розвитку суспільства: по-перше, на необхідності удосконалення управління соціальних систем; по-друге, важливості вивчення регіональних факторів впливу; по-третє, доцільності оптимізації протікання внутрішньо-суспільних процесів на основі принципів соціальної логістики. Воднораз, слід відзначити, що теоретичне та методичне обгрунтування, а також практичні аспекти соціальної логістики як сфери управління соціальноекономічними системами, інструменту розв'язання соціальних проблем і методу дослідження соціальних потоків у різних сферах детально розкрито в наукових доробках таких учених як P. Kołodziejczyk i J. Szołtysek [4], Т. Скоробогатова [5], Д. Єгоров, Р. Ніколаєв [6], М. Хайкін [7], С. Філіппов [8], Т. Ключникова [9], Є. Кейванова [10], А. Андрющенко [11], Т. Репіч і Т. Великий [12], 
Економічні науки: збірник наукових прачь Луиького національного технічного університету. Серія "Регіональна економіка". Випуск 17 (67). Редкол.: відп. ред. к.е.н., професор І.В. Кривов'язюк. Луиьк: ІВВ Луцького НТУ, 2020. 348 с.

L. Wang, S. Lee, P. Chen, X. Jiang, B. Liu [13], X. Lin, T. Chen [14], G. Lichocik, A. Sadowski [15], A. Solomein, A. Seryugin [16], M. Hess [17], J. González-Feliu [18], L. Pereira [19]. Попри значну увагу до питання впровадження соціальної логістики, до кінця не вирішеними все ще лишаються уточнення сутності поняття “соціальна логістика” в контексті розв'язання соціальнотериторіальних проблем регіонів, аналіз проблем розвитку об'єднаних територіальних громад, розкриття точок дотику соціальної логістики та розвитку ОТГ, а також особливостей управління ними.

Цілі статті. Метою дослідження є поглиблення існуючих теоретико-методичних положень i надання практичних рекомендацій, спрямованих на оптимізацію протікання внутрішньо-суспільних процесів під час управління об'єднаними територіальними громадами.

Виклад основного матеріалу. Вивчення питання соціальної логістики набуває великої актуальності в наш час, коли йде мова про сталий розвиток, соціальне підприємництво, заощадження ресурсів, збереження навколишнього середовища тощо. Такі суспільно-територіальні проблеми як неефективність соціальної підтримки окремих груп населення, недостатня розвиненість транспортного сполучення, обмеження доступу до закладів для людей із інвалідністю, низький рівень охорони здоров'я населення, недоступність муніципальних послуг у селах дають розуміння потреби та актуальності заглиблення в поняття соціальної логістики. Проблема нерозуміння терміну зумовлює труднощі у вивчені даної тематики та необхідність аналізу змісту досліджуваного поняття.

Зведемо у таблиці 1 підходи учених щодо визначення поняття "соціальна логістика".

Дослідивши підходи до визначення поняття “соціальна логістика”, слід відмітити наявність суттєвих розбіжностей у визначенні змісту досліджуваної дефініції, що підкреслює необхідність уточнення сутності даного поняття відносно сформованої нами мети дослідження. 
Економічні науки: збірник наукових прачь Луиького національного технічного університету. Серія "Регіональна економіка". Випуск 17 (67). Редкол.: відп. ред. к.е.н., професор І.В. Кривов’язюк. Луцьк: ІВВ Луцького НТУ, 2020. 348 с.

Систематизація підходів учених у визначенні сутності поняття “соціальна логістика" [4-12]

\begin{tabular}{|c|c|c|}
\hline $\begin{array}{c}\text { Змістовне } \\
\text { наповнення поняття }\end{array}$ & $\begin{array}{l}\text { Представники } \\
\text { підходу }\end{array}$ & $\begin{array}{c}\text { Особливості запропонованого } \\
\text { авторами підходу }\end{array}$ \\
\hline $\begin{array}{l}\text { Соціальна логістика } \\
\text { як управління } \\
\text { соціально- } \\
\text { економічними } \\
\text { системами, } \\
\text { суспільно-істотними } \\
\text { матеріальними } \\
\text { потоками }\end{array}$ & $\begin{array}{c}\text { P. Kołodziejczyk i } \\
\text { J. Szołtysek [4], } \\
\text { Т. Скоробогатова } \\
\text { [5], } \\
\text { М. Хайкін [7] }\end{array}$ & $\begin{array}{l}\text { Вчені роблять акцент на } \\
\text { суспільних системах та роботі } \\
\text { всередині них, забезпечення } \\
\text { якості життя, } \\
\text { покращення рінкюзії, } \\
\text { соціальних послуг за допомогою } \\
\text { оптимізації потокових процесів, } \\
\text { що протікають в соціальних } \\
\text { системах. }\end{array}$ \\
\hline $\begin{array}{l}\text { Соціальна логістика } \\
\text { як інструмент } \\
\text { забезпечення } \\
\text { ефективності } \\
\text { управління } \\
\text { соціальними } \\
\text { системами }\end{array}$ & $\begin{array}{c}\text { Є. Філіппов [8], } \\
\text { А. Андрющенко } \\
{[11]}\end{array}$ & 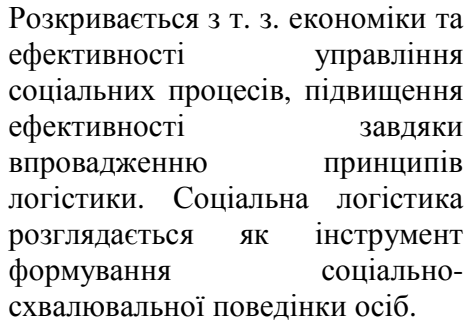 \\
\hline $\begin{array}{l}\text { Соціальна логістика } \\
\text { як метод всебічного } \\
\text { аналізу соціальних } \\
\text { потоків } \\
\text { показників у різних } \\
\text { сферах }\end{array}$ & $\begin{array}{c}\text { Д. Сгоров і } \\
\text { Р. Ніколаєв [6], } \\
\text { Т. Ключникова } \\
\text { [9], } \\
\text { Т. Репіч [12] }\end{array}$ & 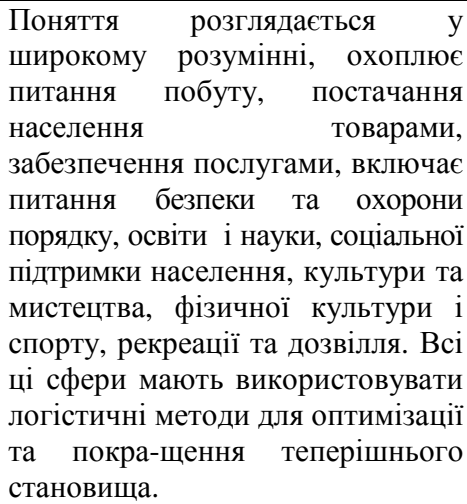 \\
\hline
\end{tabular}

Соціальна логістика - це універсальний інструмент оптимізації протікання внутрішньо-суспільних процесів, спрямований на вдосконалення управління соціальними системами, зокрема ОТГ, задля покращення їх функціонування 
Економічні науки: збірник наукових прачь Луиького національного технічного університету. Серія "Регіональна економіка". Випуск 17 (67). Редкол.: відп. ред. к.е.н., професор І.В. Кривов'язюк. Луиьк: ІВВ Луцького НТУ, 2020. 348 с.

та підвищення ефективності їх внутрішньосистемних процесів шляхом скорочення наявних суспільно-територіальних проблем.

Територіальні громади більшою мірою охоплені двома типами логістики - інформаційною (збір та обробка інформації щодо процесу децентралізації, комунікація між селами, селищами та містами) та економічною (розподілення коштів, залучення бюджету, грантові можливості). Соціальна логістика також спрямована покращити функціонування ОТГ шляхом покращення взаємодії всіх трьох видів логістики.

Аналіз розвитку ОТГ України здійснено нами на основі моніторингу процесу децентралізації влади та реформування місцевого самоврядування в період 2015-2019 рр. Встановлено, що за кількістю населення ОТГ найкращі позиції у рейтингу мають Дніпропетровська, Донецька, Запорізька, Чернігівська та Хмельницька, найгірші - Вінницька, Закарпатська, ІваноФранківська, Київська, Львівська та Рівненська області. За кількістю та площею спроможних ОТГ лідирують Дніпропетровська, Запорізька, Житомирська, Чернігівська, Хмельницька області, найгірші позиції у Донецькій, Харківській, Одеській, Київській, Закарпатській, Кіровоградській областях. Високі позиції у рейтингу стосовно кількості ОТГ, де чисельність населення менше 5 тисяч займають Харківська, Закарпатська, ІваноФранківська, Донецька та Чернівецька області. Найбільше ОТГ 3 адміністративними центрами у Сумської, Чернігівської, Житомирської, Полтавської та Харківської областей. Найкраще охоплення ОТГ перспективними планами мають Волинська, Дніпропетровська, Донецька, Запорізька, Луганська, Рівненська, Харківська та Хмельницька області, найгірше - Закарпатська, Одеська, Київська, Черкаська, Вінницька та Львівська області. Аналіз ОТГ України показав, що їх розвиток нерівномірний: до регіонів з найвищим рейтингом показників належать Житомирська, Дніпропетровська, Хмельницька, Чернігівська та Запорізька області; Кіровоградська, Закарпатська, Вінницька, Київська та Львівська області належать до регіонів 3 найнижчими рейтинговими показниками; всі інші регіони мають середній рейтинг [20]. 
Економічні науки: збірник наукових прачь Луиького національного технічного університету. Серія "Регіональна економіка". Випуск 17 (67). Редкол.: відп. ред. к.е.н., професор І.В. Кривов’язюк. Луцьк: ІВВ Луцького НТУ, 2020. 348 с.

Серед досліджуваних регіонів України виділено п’ять, де процес створення ОТГ охоплює усі райони - Волинська, Дніпропетровська, Житомирська, Запорізька та Чернігівська області. Аналізуючи логістичний аспект для цих регіонів встановлено, що одним із факторів розвитку їх ОТГ $\epsilon$ територіальне розташування. Визначено, що високорозвинені громади, як правило, знаходяться поблизу середніх та великих міст або мають прикордонне розташування. Це, відповідно, впливає на показники їх соціально-економічного розвитку. Чим вищий ступінь їх наближення до великих і середніх міст, тим кращими є відповідні соціально-економічні показники.

Подальший аналіз проблем і перспектив розвитку ОТГ здійснено на матеріалах Волинської області, зокрема Смідинської, Торчинської, Зимнівської, Любешівської та Дубівської ОТГ. Результати дослідження зведено в таблиці 2.

Таблиця 2

Результати SWOT-аналізу розвитку ОТГ Волинського регіону

\begin{tabular}{|c|c|}
\hline C 151 & \\
\hline $\begin{array}{l}\text { 1. Розвиток сільського господарства. } \\
\text { 2. Кадровий потенціал. } \\
\text { 3. Наявність земель за межами } \\
\text { населених пунктів, які потенційно } \\
\text { інвестиційно привабливі. } \\
\text { 4. Наявність транспортного } \\
\text { сполучення з містами. } \\
\text { 5. Вдале географічне розташування. } \\
\text { 6. Екологічно чиста територія. } \\
\text { 7. Перспективна молодь. } \\
\text { 8. Наявність об'єктів культури. }\end{array}$ & $\begin{array}{l}\text { 1. Поганий стан сільських доріг. } \\
\text { 2. Пасивність більшості мешканців } \\
\text { громади. } \\
\text { 3. Низький рівень розвитку } \\
\text { підприємництва. } \\
\text { 4. Незадовільна якість питної води. } \\
\text { 5. Низький рівень матеріально- } \\
\text { технічного забезпечення. } \\
\text { 6. Вирощування традиційних культур } \\
\text { при низьких закупівельних цінах. } \\
\text { 7. Відсутність організованої системи } \\
\text { вивозу сміття. } \\
\text { 8. } \text { Недосконале } \\
\text { обслуговування. }\end{array}$ \\
\hline & $\sigma a \mu_{1}$ \\
\hline $\begin{array}{l}\text { 1. Розвиток аграрного бізнесу. } \\
\text { 2. Залучення інвесторів. } \\
\text { 3. Розвиток зеленого туризму. } \\
\text { 4. Участь в міжнародних проєктах. } \\
\text { 5. Бюджетна підтримка ОТГ. } \\
\text { 6. Стимулювання підприємницьк } \\
\text { діяльності. }\end{array}$ & $\begin{array}{l}\text { 1. Зниження рівня життя. } \\
\text { 2. Недосконала податкова політика. } \\
\text { 3. Відтік молодих спеціалістів. } \\
\text { 4. Слабке, змінне законодавство. } \\
\text { 5. Корупція. } \\
\text { 6. Припинення реформи у зв'язку із } \\
\text { повільними темпами її впровадження. }\end{array}$ \\
\hline
\end{tabular}


Економічні науки: збірник наукових прачь Луиького національного технічного університету. Серія "Регіональна економіка". Випуск 17 (67). Редкол.: відп. ред. к.е.н., професор І.В. Кривов’язюк. Луцьк: ІВВ Луцького НТУ, 2020. 348 с.

SWOT-аналіз розвитку ОTГ регіону показав, що використання їх можливостей, поряд із використанням децентралізованих методів управління, може зміцнити сильні сторони та вирішити існуючі соціально-економічні проблеми. Наявний кадровий потенціал є ресурсом для участі у міжнародних проєктах, розвиток агробізнесу може підвищити рівень підприємницької активності ОТГ, проте відтік активних та кваліфікованих кадрів за кордон може обмежити розвиток існуючих підприємств та залучення іноземних інвесторів.

Застосування проблемно-цільового підходу в управлінні ОТГ забезпечує цілеспрямований напрямок соціальної логістики та оптимізації внутрішніх соціальних потоків. Використання методу “дерево проблем” (рис. 1) є основою встановлення причин гальмування розвитку ОТГ в Україні: бюрократизація процесу, низький рівень інформації про необхідність об’ єднання, слабке місцеве керівництво та корупційна складова.

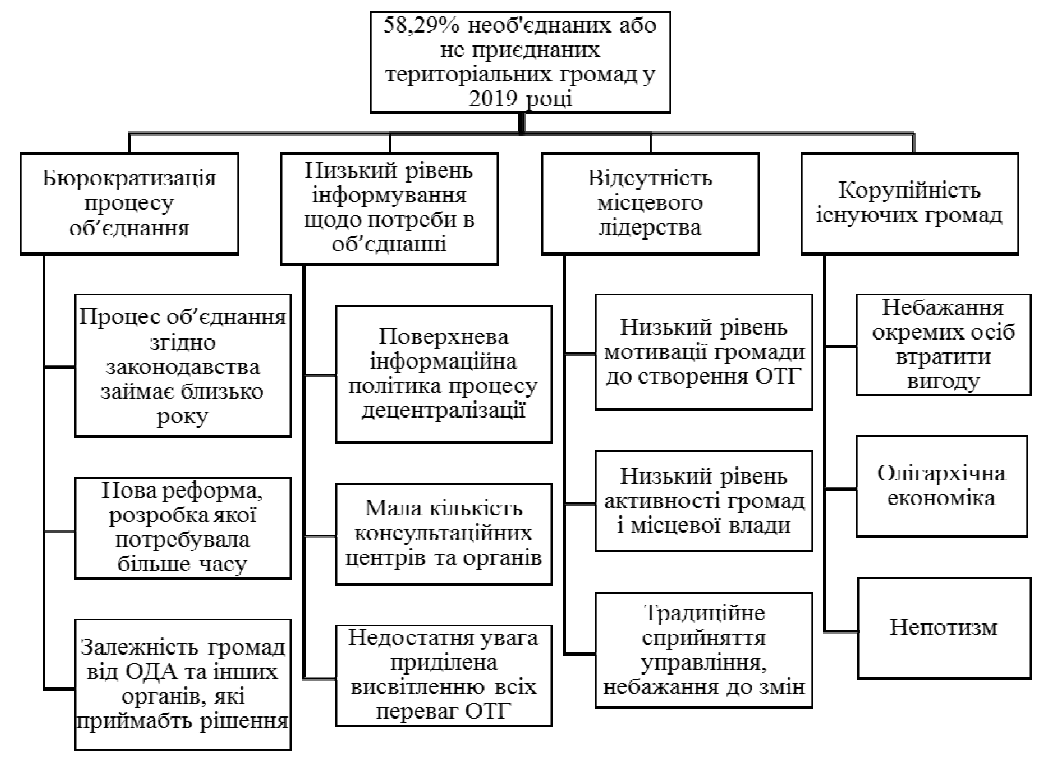

Рис. 1. Дерево проблем процесу об’єднання територіальних громад в регіонах України 
Економічні науки: збірник наукових прачь Луиького національного технічного університету. Серія "Регіональна економіка". Випуск 17 (67). Редкол.: відп. ред. к.е.н., професор І.В. Кривов'язюк. Луиьк: ІВВ Луцького НТУ, 2020. 348 с.

Соціальна логістика, що діє на основі проблемноцільового підходу, забезпечує оптимізацію рішень щодо подолання чи пом'якшення негативного впливу існуючих соціально-економічних проблем. Враховуючи, що ОТГ можуть, діючи локально, впливати на глобальні речі, доцільним $\epsilon$ впровадження реформ, які покращать існуючі внутрішньосуспільні потоки на користь розвитку сільських місцевостей.

Висновки. Вивчення питання соціальної логістики набуває актуальності, коли ми повинні говорити про сталий розвиток, соціальне підприємництво, заощадження ресурсів, збереження навколишнього середовища та інше. Необхідність іiі використання зумовлена потребою вдосконалення управління соціальними системами, покращенням їх функціонування та перебігу внутрішньо-суспільних процесів. Визначено, що завдяки взаємодії трьох видів логістики: соціальної, інформаційної та економічної, ОТГ в змозі забезпечити вирішення суспільно-територіальних проблем. Вірно налаштовані логістичні процеси дозволять громаді мінімізувати використання часових, фінансових, інформаційних ресурсів.

Аналіз функціонування ОТГ України показав, що їх розвиток за регіонами $є$ нерівномірний, що зумовлено низкою проблем, притаманних кожній визначеній території. Їх вирішення забезпечується зростанням власних доходів на одного мешканця та, одночасно, збільшенням рівня дотаційності бюджетів ОТГ регіонів.

В контексті реформи децентралізації рекомендується використовувати міжнародні пожертви, а також програми та проєкти, що сприяють розвитку ОТГ; особливу увагу слід приділити співпраці громад та вдосконаленню комунікаційних процесів із суспільством та інвесторами, розвитку соціальної взаємодії через засоби масової інформації та Інтернет.

Соціальна логістика як інструмент покращення функціонування ОТГ має забезпечувати оптимізацію внутрішньо-суспільних потоків, й зокрема через залучення громадян до вирішення існуючих територіальних проблем, застосування принципу участі, реформу децентралізації, як 
Економічні науки: збірник наукових прачь Луиького національного технічного університету. Серія "Регіональна економіка". Випуск 17 (67). Редкол.: відп. ред. к.е.н., професор І.В. Кривов’язюк. Луцьк: ІВВ Луцького НТУ, 2020. 348 с.

передачу значних повноважень та бюджетів від державних структур органам місцевого самоврядування. Адже громада розуміє краще, які виклики існують на територіальному рівні, тому може оптимізувати ресурси та використати їх з більшою користю, отримуючи значний соціальний ефект.

Відтак, подальші дослідження слід спрямувати на пошук механізмів удосконалення системи регіонального управління на основі поліпшення взаємодії ОТГ, інфраструктури регіону та місцевої влади з метою формування інвестиційно привабливих об’єктів як “зеленої”, так і “розумної” логістики.

\section{Список бібліографічного опису}

1. Кривов'язюк І.В., Кулик Ю.М. Проблеми застосування інформаційних технологій в управлінні логістичною системою підприємства. Актуальні проблеми економіки. 2013. № 12 (150). С. 254-262.

2. Кривов'язюк I.В., Усков О.Р. Управління логістичними інформаційними системами підприємства: монографія. Львів: Манускрипт, 2011. $140 \mathrm{c}$.

3. Кривов'язюк І.В., Кулик Ю.М. Управління надійністю логістичної системи підприємства: монографія. Львів: Манускрипт, 2012. 190 с.

4. Kołodziejczyk P., Szołtysek J. Epistemologia logistyki społecznej. Przeglad Organizacji. 2009. Nr. 4. pp. 21-24.

5. Скоробогатова Т.Н. Ценность и стоимость как категории: соотношение понятий, логистический аспект сравнения. Проблеми економіки. 2013. №1. С. 266-270.

6. Егоров Д.О., Николаев Р.С. Эффективность пространственновременной организации социальной инфраструктуры на примере системы здравоохранения республики Татарстан. Вестник Удмуртского университета. Серия «Биология. Науки о Земле». 2017. С. 220-230.

7. Хайкин М.М. К вопросу о формировании логистической концепции управления в сфере услуг. Известия Санкт-Петербургского государственного экономического университета. 2009. №1. URL: https://cyberleninka.ru/article/n/kvoprosu-o-formirovanii-logisticheskoy-kontseptsii-upravleniya-v-sfere-uslug-1/viewer (дата звернення: 19.09.2020).

8. Филиппов Е.Е. Социальная логистика: инструмент решения социально-общественных проблем. Управление. 2015. № 2 (8). С. 65-67.

9. Ключникова Т.Н. Социальные индикаторы преобразований в системах управления. Среднерусский вестник общественных наук. 2010. № 3. C. 29-34.

10. Кейванова Е.В. Формирование социально ориентированной логистики. Логистика. 2014. № 5. С. 55-57. 
Економічні науки: збірник наукових прачь Луиького національного технічного університету. Серія "Регіональна економіка". Випуск 17 (67). Редкол.: відп. ред. к.е.н., професор І.В. Кривов’язюк. Луцьк: ІВВ Луцького НТУ, 2020. 348 с.

11. Андрющенко А.И. Социальная логистика: инновационный механизм управления процессом консолидации общества. Социологический альманах. 2012. Випуск 3. С. 48-54.

12. Репіч Т.А., Великий Т.А. Оптимізація логістичної інфраструктури міжнародних вантажних перевезень. Ефективна економіка. 2017. № 1. URL: http://nbuv.gov.ua/UJRN/efek $2017 \quad 1 \quad 12$ (дата звернення: 19.09.2020).

13. Wang L., Lee S., Chen P., Jiang X., Liu B. Contemporary Logistics in China. Springer, Beijing. 2016. URL: https://www.springer.com/gp/book/9789811010514. (дата звернення: 20.09.2020).

14. Lin X., Chen T. Influence of Transport Development Level on Social Logistics Costs in China. In ICLEM. System Planning, Supply Chain Management, and Safety. 2014. P. 780-788.

15. Sadowski L. Sustainable logistics: social and environmental aspects. A case study of Dachser. Zeszyty Naukowe Wyższej Szkoty Bankowej we Wroctawiu Sustainable TSL. 2015. P. 109-120.

16. Соломеин А.А., Серюгин А.В. Влияние социальной логистики нефтегазового предприятия на трудовое поведение вахтовых работников. Соииодинамика. 2019. № 1. С. 81-90.

17. Neil M. Coe \& Martin Hess. Economic and social upgrading in global logistics, Global Development Institute, 2013, Working Paper Series ctg-2013-38, GDI, The University of Manchester.

18. González-Feliu J. Urban logistics and spatial territorial intelligence indicators: State-of-the-art, typology and implications for Latin American cities. Interfases. 2018. P. 135-176.

19. Pereira Morais L. \& Bacic M. J. Social and Solidarity Economy as a tool for territorial development and socio-occupational inclusion, 2017, CIRIEC Working Papers 1706, CIRIEC - Université de Liège.

20. Моніторинг процесу децентралізації влади та реформування місцевого самоврядування. Офіційний сайт децентралізації. URL: https://decentralization.gov.ua/uploads/library/file/494/10.11.2019.pdf (дата звернення: 22.09.2020).

\section{References}

1. Kryvovyazyuk I.V., Kulyk Yu.M. Problemy zastosuvannya informatsiynykh tekhnolohiy v upravlinni lohistychnoyu systemoyu pidpryyemstva. Aktual'ni problemy ekonomiky - Actual problems of economics, 2013, no. 12 (150), pp. 254-262 [in Ukrainian].

2. Kryvovyazyuk I.V., Uskov O.R. Upravlinnya lohistychnymy informatsiynymy systemamy pidpryyemstva. L'viv, Manuskrypt, 2011. 140 p. [in Ukrainian].

3. Kryvovyazyuk I.V., Kulyk Yu.M. Upravlinnya nadiynistyu lohistychnoyi systemy pidpryyemstva. L'viv, Manuskrypt, 2012. $190 \mathrm{p}$.

4. Kołodziejczyk P., Szołtysek J. Epistemologia logistyki społecznej. Przegląd Organizacji, 2009, Nr. 4, pp. 21-24. 
Економічні науки: збірник наукових прачь Луиького національного технічного університету. Серія "Регіональна економіка". Випуск 17 (67). Редкол.: відп. ред. к.е.н., професор І.В. Кривов’язюк. Луцьк: ІВВ Луцького НТУ, 2020. 348 с.

5. Skorobohatova T.N. Tsennost' y stoymost' kak katehoryy: sootnoshenye ponyatyy, lohystycheskyy aspekt sravnenyya. Problemy ekonomiky - The problems of economy, 2013, no. 1, pp. 266-270 [in Ukrainian].

6. Egorov D.O., Nikolaev R.S. Jeffektivnost' prostranstvenno-vremennoj organizacii social'noj infrastruktury na primere sistemy zdravoohranenija respubliki Tatarstan. Vestnik Udmurtskogo universiteta. Serija «Biologija. Nauki o Zemle»Bulletin of Udmurt University. Series Biology. Earth Sciences, 2017, pp. 220-230. [In Russsian].

7. Hajkin M.M. K voprosu o formirovanii logisticheskoj koncepcii upravlenija v sfere uslug. Izvestija Sankt-Peterburgskogo gosudarstvennogo jekonomicheskogo universiteta, 2009, no. 1. Available at: https://cyberleninka.ru/article/n/k-voprosu-oformirovanii-logisticheskoy-kontseptsii-upravleniya-v-sfere-uslug-1/viewer (accessed 19.09.2020) [In Russsian].

8. Filippov E.E. Social'naja logistika: instrument reshenija social'noobshhestvennyh problem. Upravlenie - Management, 2015, no. 2 (8), pp. 65-67 [In Russsian].

9. Kljuchnikova T.N. Social'nye indikatory preobrazovanij $\mathrm{v}$ sistemah upravlenija. Srednerusskij vestnik obshhestvennyh nauk - Central Russian Journal of Social Sciences, 2010, no. 3, pp. 29-34 [In Russsian].

10. Kejvanova E.V. Formirovanie social'no orientirovannoj logistiki. Logistika - Logistics, 2014, no. 5, pp. 55-57 [In Russsian].

11. Andrjushhenko A.I. Social'naja logistika: innovacionnyj mehanizm upravlenija processom konsolidacii obshhestva. Sociologicheskij al'manah Sociological almanac, 2012, no. 3, pp. 48-54 [In Russsian].

12. Repich T.A., Velykyy T.A. Optymizatsiya lohistychnoyi infrastruktury mizhnarodnykh vantazhnykh perevezen'. Efektyvna ekonomika, 2017, no 1. Available at: http://nbuv.gov.ua/UJRN/efek_2017_1_12 (accessed 19.09.2020) [in Ukrainian].

13. Wang L., Lee S., Chen P., Jiang X., Liu B. Contemporary Logistics in China. Springer, $\quad$ Beijing, $2016 . \quad$ Available at: https://www.springer.com/gp/book/9789811010514 (accessed 19.09.2020).

14. Lin X., Chen T. Influence of Transport Development Level on Social Logistics Costs in China. In ICLEM. System Planning, Supply Chain Management, and Safety, 2014, pp. 780-788.

15. Sadowski L. Sustainable logistics: social and environmental aspects. A case study of Dachser. Zeszyty Naukowe Wyższej Szkoły Bankowej we Wrocławiu Sustainable TSL, 2015, pp. 109-120.

16. Solomein A.A., Serjugin A.V. Vlijanie social'noj logistiki neftegazovogo predprijatija na trudovoe povedenie vahtovyh rabotnikov. Sociodinamika Sociodynamics, 2019, no. 1, pp. 81-90 [In Russsian].

17. Neil M. Coe \& Martin Hess. Economic and social upgrading in global logistics, Global Development Institute, 2013, Working Paper Series ctg-2013-38, GDI, The University of Manchester. 
Економічні науки: збірник наукових прачь Луиького національного технічного університету. Серія "Регіональна економіка". Випуск 17 (67). Редкол.: відп. ред. к.е.н., професор І.В. Кривов’язюк. Луцьк: ІВВ Луцького НТУ, 2020. 348 с.

18. González-Feliu J. Urban logistics and spatial territorial intelligence indicators: State-of-the-art, typology and implications for Latin American cities. Interfases, 2018, pp. 135-176.

19. Leandro PEREIRA MORAIS \& Miguel Juan BACIC. Social and Solidarity Economy as a tool for territorial development and socio-occupational inclusion, 2017, CIRIEC Working Papers 1706, CIRIEC - Université de Liège.

20. Monitorynh protsesu detsentralizatsiyi vlady ta reformuvannya mistsevoho samovryaduvannya. Ofitsiynyy sayt detsentralizatsiyi. Available at: https://decentralization.gov.ua/uploads/library/file/494/10.11.2019.pdf $\quad$ (accessed 22.09.2020). 